ҚАЗАҚСТАН РЕСПУБЛИКАСЫ

ҰЛТТЫҚ ҒЫЛЫМ АКАДЕМИЯСЫНЫН

БАЯНДАМАЛАРЫ

ДОКЛАДЫ

НАЦИОНАЛЬНОЙ АКАДЕМИИ НАУК

РЕСПУБЛИКИ КАЗАХСТАН

\title{
REPORTS
}

OF THE NATIONAL ACADEMY OF SCIENCES

OF THE REPUBLIC OF KAZAKHSTAN

PUBLISHED SINCE 1944

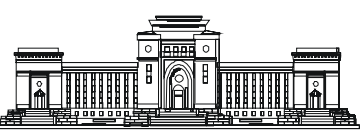




\author{
Ба с редак т о ры \\ х.ғ.д., проф., ҚР ҰҒА академигі \\ М.Ж. Жұрынов
}

Р едакция алқа сы:

\begin{abstract}
Адекенов С.М. проф., академик (Қазақстан) (бас ред. орынбасары)
Величкин В.И. проф., корр.-мүшесі (Ресей)

Вольдемар Вуйцик проф. (Польша)

Гончарук В.В. проф., академик (Украина)

Гордиенко А.И. проф., академик (Белорус)

Дука Г. проф., академик (Молдова)

Илолов М.И. проф., академик (Тәжікстан)

Кригер Виктор проф. (Германия)

Леска Богуслава проф. (Польша)

Локшин В.Н. проф., чЛ.-корр. (Қазақстан)

Нараев В.Н. проф. (Ресей)

Неклюдов И.М. проф., академик (Украина)

Нур Изура Удзир проф. (Малайзия)

Перни Стефано проф. (Ұлыбритания)

Потапов В.А. проф. (Украина)

Прокопович Полина проф. (Ұлыбритания)

Омбаев А.М. проф., корр.-мүшесі (Қазақстан)

Өтелбаев М.О. проф., академик (Қазақстан)

Садыбеков М.А. проф., корр.-мүшесі (Қазақстан)

Сатаев М.И. проф., корр.-мүшесі (Қазақстан)

Северский И.В. проф., академик (Қазақстан)

Сикорски Марек проф., (Польша)

Рамазанов Т.С. проф., академик (Қазақстан)

Такибаев Н.Ж. проф., академик (Қазақстан), бас ред. орынбасары

Харин С.Н. проф., академик (Қазақстан)

Чечин Л.М. проф., корр.-мүшесі (Қазақстан)

Харун Парлар проф. (Германия)

Энджун Гао проф. (Қытай)

Эркебаев А.Э. проф., академик (Қырғыстан)
\end{abstract}

«Қазақстан Республикасы Ұлттық ғылым академиясының баяндамалары»

ISSN 2518-1483 (Online),

ISSN 2224-5227 (Print)

Меншіктенуші: «Қазақстан Республикасының Ұлттық ғылым академиясы» Республикалық қоғамдық бірлестігі (Алматы қ.).

Қазақстан республикасының Мәдениет пен ақпарат министрлігінің Ақпарат және мұрағат комитетінде 01.06.2006 ж. берілген №5540-Ж мерзімдік басылым тіркеуіне қойылу туралы куәлік.

Мерзімділігі: жылына 6 рет.

Тиражы: 500 дана.

Редакцияның мекенжайы: 050010, Алматы қ., Шевченко көш., 28; 219, 220 бөл.; тел.: 272-13-19, 272-13-18, http://reports-science.kz/index.php/en/archive

(C) Қазақстан Республикасының Ұлттық ғылым академиясы, 2020

Типографияның мекенжайы: «NurNaz GRACE», Алматы қ., Рысқұлов көш., 103. 


\title{
Главны й редактор \\ д.х.н., проф., академик НАН РК \\ М. Ж. Журинов \\ Р едакци онная коллегия:
}

\author{
Адекенов С.М. проф., академик (Казахстан) (зам. гл. ред.) \\ Величкин В.И. проф., чл.-корр. (Россия) \\ Вольдемар Вуйцик проф. (Польша) \\ Гончарук В.В. проф., академик (Украина) \\ Гордиенко А.И. проф., академик (Беларусь) \\ Дука Г. проф., академик (Молдова) \\ Илолов М.И. проф., академик (Таджикистан) \\ Кригер Виктор проф. (Германия) \\ Леска Богуслава проф. (Польша) \\ Локшин В.Н. проф., чл.-корр. (Казахстан) \\ Нараев В.Н. проф. (Россия) \\ Неклюдов И.М. проф., академик (Украина) \\ Нур Изура Удзир проф. (Малайзия) \\ Перни Стефано проф. (Великобритания) \\ Потапов В.А. проф. (Украина) \\ Прокопович Полина проф. (Великобритания) \\ Омбаев А.М. проф., чл.-корр. (Казахстан) \\ Отелбаев М.О. проф., академик (Казахстан) \\ Садыбеков М.А. проф., чл.-корр. (Казахстан) \\ Сатаев М.И. проф., чл.-корр. (Казахстан) \\ Северский И.В. проф., академик (Казахстан) \\ Сикорски Марек проф., (Польша) \\ Рамазанов Т.С. проф., академик (Казахстан) \\ Такибаев Н.Ж. проф., академик (Казахстан), зам. гл. ред. \\ Харин С.Н. проф., академик (Казахстан) \\ Чечин Л.М. проф., чл.-корр. (Казахстан) \\ Харун Парлар проф. (Германия) \\ Энджун Гао проф. (Китай) \\ Эркебаев А.Э. проф., академик (Кыргызстан)
}

Доклады Национальной академии наук Республики Казахстан»

ISSN 2518-1483 (Online),

ISSN 2224-5227 (Print)

Собственник: Республиканское общественное объединение «Национальная академия наук Республики Казахстан» (г. Алматы).

Свидетельство о постановке на учет периодического печатного издания в Комитете информации и архивов Министерства культуры и информации Республики Казахстан №5540-Ж, выданное 01.06.2006 г.

Периодичность: 6 раз в год.

Тираж: 500 экземпляров

Адрес редакции: 050010, г.Алматы, ул.Шевченко, 28; ком. 219, 220; тел. 272-13-19, 272-13-18,

http://reports-science.kz/index.php/en/archive

(C) Национальная академия наук Республики Казахстан, 2020 г. 
Editorin chief

doctor of chemistry, professor, academician of NAS RK

M.Zh. Zhurinov

Editorial board:

Adekenov S.M. prof., academician (Kazakhstan) (deputy editor in chief)

Velichkin V.I. prof., corr. member (Russia)

Voitsik Valdemar prof. (Poland)

Goncharuk V.V. prof., academician (Ukraine)

Gordiyenko A.I. prof., academician (Belarus)

Duka G. prof., academician (Moldova)

Ilolov M.I. prof., academician (Tadjikistan)

Krieger Viktor prof. (Germany)

Leska Boguslava prof. (Poland)

Lokshin V.N. prof., corr. member (Kazakhstan)

Narayev V.N. prof. (Russia)

Nekludov I.M. prof., academician (Ukraine)

Nur Izura Udzir prof. (Malaysia)

Perni Stephano prof. (Great Britain)

Potapov V.A. prof. (Ukraine)

Prokopovich Polina prof. (Great Britain)

Ombayev A.M. prof., corr. member (Kazakhstan)

Otelbayv M.O. prof., academician (Kazakhstan)

Sadybekov M.A. prof., corr. member (Kazakhstan)

Satayev M.I. prof., corr. member (Kazakhstan)

Severskyi I.V. prof., academician (Kazakhstan)

Sikorski Marek prof., (Poland)

Ramazanov T.S. prof., academician (Kazakhstan)

Takibayev N.Zh. prof., academician (Kazakhstan), deputy editor in chief

Kharin S.N. prof., academician (Kazakhstan)

Chechin L.M. prof., corr. member (Kazakhstan)

Kharun Parlar prof. (Germany)

Endzhun Gao prof. (China)

Erkebayev A.Ye. prof., academician (Kyrgyzstan)

Reports of the National Academy of Sciences of the Republic of Kazakhstan.

ISSN 2224-5227

ISSN 2518-1483 (Online),

ISSN 2224-5227 (Print)

Owner: RPA "National Academy of Sciences of the Republic of Kazakhstan" (Almaty).

The certificate of registration of a periodic printed publication in the Committee of Information and Archives of the Ministry of Culture and Information of the Republic of Kazakhstan N 5540-Ж, issued 01.06.2006.

Periodicity: 6 times a year.

Circulation: 500 copies.

Editorial address: 28, Shevchenko str., of. 219, 220, Almaty, 050010, tel. 272-13-19, 272-13-18, http://reports-science.kz/index.php/en/archive

(C) National Academy of Sciences of the Republic of Kazakhstan, 2020

Address of printing house: «NurNaz GRACE», 103, Ryskulov str, Almaty. 


\title{
REPORTS OF THE NATIONAL ACADEMY OF SCIENCES
} OF THE REPUBLIC OF KAZAKHSTAN

ISSN 2224-5227

Volume 2, Number 330 (2020), $14-20$

https://doi.org/10.32014/2020.2518-1483.26

UDK 521.1

MRNTI 41.03.02

\author{
M.Zh. Minglibayev, A.B. Kosherbayeva
}

Al-Farabi Kazakh National University, Almaty, Kazakhstan.

E-mail: minglibayev@gmail.com, kosherbaevaayken@gmail.com

\section{DIFFERENTIAL EQUATIONS OF PLANETARY SYSTEMS}

\begin{abstract}
In this article will be considered many spherical bodies problem with variable masses, varying nonisotropic at different rates as celestial-mechanical model of non-stationary planetary systems. In this article were obtained differential equations of motions of spherical bodies with variable masses to reach purpose exploration of evolution planetary systems. The scientific importance of the work is exploration to the effects of masses' variability of the dynamic evolution of the planetary system for a long period of time. According to equation of Mescherskiy, we obtained differential equations of motions of planetary systems in the absolute coordinates system and the relative coordinates system. On the basis of obtained differential equations in the relative coordinates system, we derived equations of motions in osculating elements in form of Lagrange's equations and canonically equations in osculating analogs second systems of Poincare's elements on the base aperiodic motion over the quasi-canonical cross- section.
\end{abstract}

Keywords: non-stationary star, planetary systems, variable mass, the many-body problem, osculating elements.

1. Introduction. Modern astronomical observations show, that the central star and the planetary system around it, in many cases, are genetically mutually associated [1-3]. With this regard, exploration of evolution of planetary systems with it's central star are represented the interests. The evolution of planetary systems in its non-stationary stage is special interesting, when main factor of dynamical evolution is variable masses of planets and the central star [4-7].

With this regard, we investigate as a celestial-mechanical model of the planetary system, $n+1$ body problems $(n \geq 3)$ with masses, varying non-isotropic at different rates [1-5]. Bodies are considered as spherical bodies, and also with spherical distributions of masses. For this reason, they can be considered as Newtonian interaction of pointedly bodies, which positioned in the center of these spherical bodies. Based on the equation of Mescherskiy, we obtained equations of motions of many planetary problems with variable masses. In this case, masses of bodies varying non-isotropic at different rates with the presence of reactive forces in the absolute rectangular Cartesian reference frame. Further, we obtained equations of motions of considering the problem in the relative coordinates system. The center of the relative coordinates system is located in the center of the most massive body - parent star. Bases on obtained equations of motions in the relative coordinates system, we derived equations of perturbative motions in the various osculating systems. Unperturbed motions are accepted as aperiodic motions over a quasicanonical cross-section [7].

\section{Differential equations of motions of problem.}

2.1 Statement of problem and differential equations of motions in the absolute coordinates system.

Let us consider the planetary system, which consists of $n+1$ inter-gravitating spherical celestial bodies with variable masses. The central body is denoted by $T_{0}$. Denoted body $T_{0}$ has mass $m_{0}$, alongside this, it is considered as parent star of the planetary system. Planets are designated by $T_{i}$, and corresponding masses of planets are represented by $m_{i}$, here $(i=1,2, \ldots, n)$. Locations of planets are such, that $T_{i}$ is internal planet relative to planet $T_{i+1}$, and is external planet relative to planet $T_{i-1}$. Masses of bodies vary non-isotropically, as presented in the following form

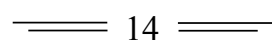




$$
m_{0}=m_{0}(t), \quad m_{1}=m_{1}(t), \quad \ldots, \quad m_{n}=m_{n}(t)
$$

Let rates of masses variation are different [7-8]

$$
\frac{\dot{m}_{i}}{m_{i}} \neq \frac{\dot{m}_{k}}{m_{k}}, \quad i=0, . ., n, \quad k=0, \ldots n, \quad i \neq k,
$$

Mass of the parent star is more than the mass of certain planet in the considered system

$$
m_{0} \gg m_{i} \quad(\mathrm{i}=1, \ldots, n) .
$$

On the basis of the Mescherskiy equation and following by L.G. Lukyanov [9], we obtained differential equations of motions in the absolute coordinates system

$$
m_{i} \ddot{\vec{R}}_{i}=f m_{i} \sum_{k=0}^{n} \frac{m_{k} \vec{R}_{i k}}{R_{i k}^{3}}+\dot{m}_{i} \vec{V}_{i}, \quad i=0,1, \ldots n,
$$

where $f$ - the gravitational constant, $\vec{R}_{i}$ - radius-vectors of centers of spherical bodies, $\vec{R}_{i k}-$ mutual distances of the center of spherical bodies, sign "stroke" when summing denotes, that $i \neq k, \vec{V}_{i}-$ the relative velocity of separated particles

$$
\vec{V}_{i}=\vec{u}_{i}-\dot{\vec{R}}_{i},
$$

when $\vec{u}_{i}$ - the absolute velocity of separated particles.

Usually, in observational astronomy, of celestial bodies are defined the law of varying mass, which presented by ratios (2.1)-(2.2), also the relative velocity of separated particles (2.5). For example, the relative velocity of separated particles from Wolf-Rayet star (WR) is $1000 \mathrm{~km} / \mathrm{s}$, at the same time, the rate of decrease of masses due to star wind is $\dot{M} \approx-10^{-5} M_{\odot} /$ год. Stars of spectral class $M$ shed mass at the rate $\dot{M} \approx-10^{-6} M_{\odot} /$ year [10]. For this reason, we will consider, that magnitudes (2.1)-(2.2) and (2.5) known.

\subsection{Differential equations of motions in the relative coordinates system.}

Let's introduce enter the relative coordinates system with beginning in the center of parent star $T_{0}$, axes which parallel corresponding axes of the absolute coordinates system.

Let's introduce following notations

$$
\vec{R}_{0 i}=\vec{R}_{i}-\vec{R}_{0}=\vec{r}_{i}
$$

where $\vec{R}_{i}$ and $\vec{R}_{0}$ - correspondingly radius-vectors of spherical bodies and of the parent star relative to the center of the absolute coordinates system, $\vec{R}_{0 i}$ - radius-vectors of bodies $T_{i}$ from the center of the relative coordinates system.

Thus, equations of motions of $n$ planets (2.4) in the relative coordinates system may be written the following

$$
\ddot{\vec{r}}_{i}=-f \frac{\left(m_{0}+m_{i}\right)}{r_{i}^{3}} \vec{r}_{i}+\frac{\dot{m}_{i}}{m_{i}} \vec{V}_{0 i}+f \sum_{k=1}^{n} m_{k}\left(\frac{\vec{r}_{i k}}{r_{i k}^{3}}-\frac{\vec{r}_{k}}{r_{k}^{3}}\right)
$$

Taking into consideration ratio (2.6) may be rewritten differential equations of motions of $n$ bodies (2.7) in the following way

$$
\ddot{\vec{r}}_{i}=-f \frac{\left(m_{0}+m_{i}\right)}{r_{i}^{3}} \vec{r}_{i}+\frac{\dot{m}_{i}}{m_{i}} \vec{V}_{i}-\frac{\dot{m}_{0}}{m_{0}} \vec{V}_{0}+f \sum_{k=1}^{n} m_{k}\left(\frac{\vec{r}_{i k}}{r_{i k}^{3}}-\frac{\vec{r}_{k}}{r_{k}^{3}}\right)
$$


Differential equations of motion of $n$ body (2.8) may be represented as following

$$
\begin{aligned}
& \ddot{x}_{i}=-f \frac{\left(m_{0}+m_{i}\right)}{r_{i}^{3}} x_{i}+\frac{\dot{m}_{i}}{m_{i}} V_{i x}-\frac{\dot{m}_{0}}{m_{0}} V_{0 x}+f \sum_{k=1}^{n} m_{k}\left(\frac{x_{k}-x_{i}}{\Delta_{i k}^{3}}-\frac{x_{k}}{r_{k}^{3}}\right) \\
& \ddot{y}_{i}=-f \frac{\left(m_{0}+m_{i}\right)}{r_{i}^{3}} y_{i}+\frac{\dot{m}_{i}}{m_{i}} V_{i y}-\frac{\dot{m}_{0}}{m_{0}} V_{0 y}+f \sum_{k=1}^{n} m_{k}\left(\frac{y_{k}-y_{i}}{\Delta_{i k}^{3}}-\frac{y_{k}}{r_{k}^{3}}\right) \\
& \ddot{z}_{i}=-f \frac{\left(m_{0}+m_{i}\right)}{r_{i}^{3}} z_{i}+\frac{\dot{m}_{i}}{m_{i}} V_{i z}-\frac{\dot{m}_{0}}{m_{0}} V_{0 z}+f \sum_{k=1}^{n} m_{k}\left(\frac{z_{k}-z_{i}}{\Delta_{i k}^{3}}-\frac{z_{k}}{r_{k}^{3}}\right)
\end{aligned}
$$

where distance between bodies $\Delta_{i k}$ are presented in as

$$
\Delta_{i k}=\sqrt{\left(x_{k}-x_{i}\right)^{2}+\left(y_{k}-y_{i}\right)^{2}+\left(z_{k}-z_{i}\right)^{2}}
$$

In that way, differential equations of motions of $n$ bodies are reduced in the relative coordinates system.

3. Equations of motions in osculating elements of aperiodic motion over a quasi-canonical crosssection.

3.1 Highlighting perturbed functions. Equations of motions (2.8) are rewritten as following

$$
\ddot{\vec{r}}_{i}+f \frac{\left(m_{0}+m_{i}\right)}{r_{i}^{3}} \vec{r}_{i}-\frac{\ddot{\gamma}_{i}}{\gamma_{i}} \vec{r}_{i}=\vec{F}_{i, \text { возM }}
$$

where

$$
\begin{gathered}
\gamma_{i}=\frac{m_{0}\left(t_{0}\right)+m_{i}\left(t_{0}\right)}{m_{0}(t)+m_{i}(t)} \\
\vec{F}_{i, \text { возM }}=\vec{\Phi}_{r i}+\vec{F}_{g i}+\vec{\Pi}_{i} \\
\vec{\Phi}_{r i}=\frac{\dot{m}_{i}}{m_{i}} \vec{V}_{i}-\frac{\dot{m}_{0}}{m_{0}} \vec{V}_{0}, \\
\vec{F}_{g i}=f \sum_{k=1}^{n} m_{k}\left(\frac{\vec{r}_{i k}}{r_{i k}^{3}}-\frac{\vec{r}_{k}}{r_{k}^{3}}\right) \\
\vec{\Pi}_{i}=-\frac{\ddot{\gamma}_{i}}{\gamma_{i}} \vec{r}
\end{gathered}
$$

In the case, when the perturbative force (3.3) equals to zero, equations (3.1) describe aperiodic motion over a quasi-canonical cross-section.

We can also rewrite the perturbative function (3.3) in another way

$$
\begin{gathered}
\vec{F}_{i, \text { возм }}=\operatorname{grad}_{\vec{r}_{i}} W_{i} \\
W_{i}=W_{r i}+W_{c i}+W_{g i}
\end{gathered}
$$

where components of force function have view

$$
\begin{gathered}
W_{r i}=\left(\frac{\dot{m}_{i}}{m_{i}} \vec{V}_{i}-\frac{\dot{m}_{0}}{m_{0}} \vec{V}_{\alpha i}\right) \cdot \vec{r}_{i} \\
W_{g i}=f \sum_{k=1}^{n} m_{k}\left(\frac{1}{r_{i k}}-\frac{\vec{r}_{i} \cdot \vec{r}_{k}}{r_{k}^{3}}\right) \\
=16=
\end{gathered}
$$




$$
W_{c i}=-\frac{\ddot{\gamma}_{i}}{2 \gamma_{i}} r_{i}^{2}
$$

In this way, by use designations (3.7)-(3.11) we can write equations of motions $n$ planet (3.1) in following way

$$
\ddot{\vec{r}}_{i}+f \frac{\left(m_{0}+m_{i}\right)}{r_{i}^{3}} \vec{r}_{i}-\frac{\ddot{\gamma}_{i}}{\gamma_{i}} \vec{r}_{i}=\operatorname{grad}_{\vec{r}_{i}} W_{i}
$$

Obtained equations of motions (3.12) convenient for using theories of perturbation, which formulated for such non-stationary systems [7].

\subsection{Differential equations of motions for systems of osculating elements in form of Lagrange's} equations

According to equation of the relative motion of $n$ planets (3.12) with beginning in the center of the parent star, we can write different differential equations of motions in different systems of osculating elements, on the basis of aperiodic motion over a quasi-canonical cross-section. We consider equations of perturbative motions in osculating elements $\left(a_{i}, e_{i}, i_{i}, \Omega_{i}, \pi_{i}, \varepsilon_{i}\right)$ in the form of Lagrange's equations

$$
\begin{aligned}
& \dot{a}_{i}=\frac{2}{n_{i} a_{i}} \frac{\partial W_{i}}{\partial \varepsilon_{i}}, \\
& \dot{e}_{i}=\frac{\sqrt{1-e_{i}^{2}}}{n_{i} a_{i}^{2} e_{i}} \frac{\partial W_{i}}{\partial \pi_{i}}-\frac{e_{i} \sqrt{1-e_{i}^{2}}}{1+\sqrt{1-e_{i}^{2}}} \frac{1}{n_{i} a_{i}^{2}} \frac{\partial W_{i}}{\partial \varepsilon_{i}}, \\
& \frac{d i}{d t}=-\frac{\operatorname{cosec} i_{i}}{n_{i} a_{i}^{2} \sqrt{1-e_{i}^{2}}} \frac{\partial W_{i}}{\partial \Omega_{i}}-\frac{\operatorname{tg}(i / 2)}{n_{i} a^{2} \sqrt{1-e_{i}^{2}}}\left(\frac{\partial W_{i}}{\partial \pi_{i}}+\frac{\partial W_{i}}{\partial \varepsilon_{i}}\right), \\
& \dot{\Omega}_{i}=\frac{\operatorname{cosec} i_{i}}{n_{i} a_{i}^{2} \sqrt{1-e_{i}^{2}}} \frac{\partial W_{i}}{\partial i_{i}}, \\
& \dot{\pi}_{i}=\frac{\operatorname{tg}(i / 2)}{n_{i} a_{i}^{2} \sqrt{1-e_{i}^{2}}} \frac{\partial W_{i}}{\partial i_{i}}+\frac{\sqrt{1-e^{2}}}{n_{i} a_{i}^{2} e_{i}} \frac{\partial W_{i}}{\partial e_{i}}, \\
& \dot{\varepsilon}_{i}=-\frac{2}{n_{i} a_{i}} \frac{\partial W_{i}}{\partial a_{i}}+\frac{\operatorname{tg}(i / 2)}{n_{i} a_{i}^{2} \sqrt{1-e_{i}^{2}}} \frac{\partial W_{i}}{\partial i_{i}}+\frac{e_{i} \sqrt{1-e_{i}^{2}}}{1+\sqrt{1-e_{i}^{2}}} \frac{1}{n_{i} a_{i}^{2}} \frac{\partial W_{i}}{\partial e_{i}},
\end{aligned}
$$

where $a_{i}$ - analog of a semimajor, $e_{i}$ - analog of a eccentricity, $i$ - analog of an angle of inclination of orbit plane, $\Omega_{i}$ - analog of a longitude of acsending angle, $\pi_{i}$ - analog of a longitude of pericenter, $\varepsilon_{i}-$ analog of a longitude of epoch. In the case, when masses of considering bodies are constants, all of these elements will turn into corresponding Kepler elements.

In equations (3.13)-(3.18) the force function (3.8)-(3.11) must be represented in explicit form

$$
W_{i}=W_{i}\left(t_{i}, a_{i}, e_{i}, i_{i}, \Omega_{i}, \pi_{i}, \varepsilon_{i}\right) .
$$

Expressions of perturbative functions (3.19) via osculating elements, are cumbersome and laborious work. Such work, on today's day, as a rule, are implemented with using of method of computer algebra $[11,12]$.

\subsection{Equations of perturbative motions in analog of second systems of canonical elements of}

\section{Poincare}

In some cases, it is convenient to use the canonical theory of perturbation for considerative nonstationary gravitational systems. For our purposes, analogs second systems of canonical elements Poincare $\left(\Lambda_{i}, \lambda_{i}, \xi_{i}, \eta_{i}, p_{i}, q_{i}\right)$ are preferable, which are introduce by [7]. 


$$
\begin{aligned}
\Lambda_{i} & =\sqrt{\mu_{i 0}} \sqrt{a_{i}} \\
\lambda_{i} & =l_{i}+\Omega_{i}+\omega_{i} \\
\xi_{i} & =\sqrt{2 \sqrt{\mu_{i 0}} \sqrt{a_{i}}\left(1-\sqrt{1-e_{i}^{2}}\right)} \operatorname{Cos} \pi_{i} \\
\eta_{i} & =-\sqrt{2 \sqrt{\mu_{i 0}} \sqrt{a_{i}}\left(1-\sqrt{1-e_{i}^{2}}\right)} \operatorname{Sin} \pi_{i} \\
p_{i} & =\sqrt{2 \sqrt{\mu_{i 0}} \sqrt{a_{i}} \sqrt{1-e_{i}^{2}}\left(1-\operatorname{Cosi} i_{i}\right)} \operatorname{Cos} \Omega_{i} \\
q_{i} & =-\sqrt{2 \sqrt{\mu_{i 0}} \sqrt{a_{i}} \sqrt{1-e_{i}^{2}}\left(1-\operatorname{Cosi} i_{i}\right)} \operatorname{Sin} \Omega_{i}
\end{aligned}
$$

The system of differential equations of canonical osculating elements of $n$ body in analogs of second systems of Poincare variables has the form [7]

where

$$
\begin{array}{ll}
\dot{\Lambda}_{i}=\frac{\partial R_{i}^{*}}{\partial \lambda_{i}}, & \dot{\xi}_{i}=\frac{\partial R_{i}^{*}}{\partial \eta_{i}},
\end{array}
$$

$$
R_{i}^{*}=\frac{\mu_{0}^{2}}{2 \Lambda_{i}^{2}} \cdot\left[\frac{m_{0}(t)+m_{i}(t)}{m_{0}\left(t_{0}\right)+m_{i}\left(t_{0}\right)}\right]^{2}+W_{i}\left(t, \Lambda_{i}, \xi_{i}, p_{i}, \lambda_{i}, \eta_{i}, \mathrm{q}_{i}\right)
$$

Canonical equations of perturbative motions (3.21) are very convenient to describe to dynamical evolution of planetary systems, when inclinations of orbital planes and analogs of eccentricities are quite small.

\section{Conclusion}

In this article we obtained different forms of differential equations for non-stationary planetary systems, which contains $n$ planet. Perturbative function is alloted, equations of perturbative motions are leaded in form of Lagrange's equations and in analogs of second systems of Poincare's canonical elements. In the further, we plan to obtain decompositions of perturbative function via osculating elements with using of systems of analitical calculations "Wolfram Mathematica". Obtained equations will use for exploration to effects of variable of masses during of evolution of ekzoplanety systems. At the same time, effects of decreases of masses of the parent star and increases of masses of planets will be taken into account due to accretion of particles from residues of the protoplanetary disk.

\section{М.Ж. Минглибаев, А.Б. Кошербаева}

Әл-Фараби атындағы КазҰУ, Алматы, Қазақстан

\section{ПЛАНЕТА ЖУЙЕЛЕРІНІН ДИФФЕРЕНЦИАЛДЫҚ ТЕНДЕУЛЕРІ}

Аннотация. Экзопланета жүйесінің пайда болуын және эволюциясын зерттеу - аспан механикасы мен астрономияның өзекті мәселелерінің бірі. 1950 жылы экзопланета жүйелерінің ашылуы болды. Экзопланета жүйелері анықталған кезден бастап, олардың пайда болуы мен динамикалық эволюциясы әртүрлі әдістермен зерттеліп келеді. Қазіргі таңда экзопланета жүйелерін табудың сегіз әдісі қолданылады. Бірінші әдіс - сәуле жылдамдығы әдісі, осы әдісті қолдану арқылы орталық жұлдыз төңірегіндегі экзопланеталық жүйелер ашыла бастады. Екінші әдіс - «Кеплер» ғарыш телескопы миссиясының пайда болуына байланысты транзиттер әдісі. Бұл әдістерде, денелердің массалары тұрақты ретінде қарастырылады және классикалық кеплерлік қозғалыс формулалары, классикалық аспан механикасы қолданылады. Алайда шынайы ғарыштық жүйелер стационар емес. Бейстационар гравитацияланатын денелердің массаларының айнымалылығы, өлшемдерінің 
айнымалылығы және пішіндерінің айнымалылығы сияқты динамикалық әсерлердің комбинациясы гравитацияланатын жүйелердің эволюция жолдарының мол түрін анықтайды. Аспан механикасы аспектінде осы құбылыстарды зерттеу планета жүйелерінің динамикалық эволюция табиғатын түсіну үшін қажет. Қазіргі таңда астрономияның бейстационар динамикалық мәселелері қарқынды өңделіп келеді. Аспан денелері массаларының өлшемдерінің, пішіндерінің және басқа да физикалық параметрлерінің уақыт бойынша өзгерісі эксперименттік анықтама беруге алып келеді. Сондықтан осы физикалық параметрлерді негізге ала отырып, динамикалық мәселелерді құру және зерттеу қажеттілік тудырады. Көптеген белгілі экзопланеталар F, G, K және M спектральді кластарға кіретін жұлдыздар төңірегінде қозғалыс жасайды. Бұл жұлдыздардың массалары айнымалы және планета қозғалысына орталық жұлдыз массасының айнымалылық әсері аз зерттелген. Алайда орталық жұлдыз массасының айнымалылығын ескерген жағдайдағы дифференциалдық қозғалыс теңдеуі интегралданбайды, сондықтан мәселе ұйытқу теориясы әдістерімен зерттеледі. Бұл тұрғыдан, ұйытқыған қозғалыстың канондық теңдеулері және Лагранж теңдеулері түріндегі квазиконустық қима бойынша, апериодтық қозғалыс негізіндегі ұйытқыған қозғалыс теңдеулері қолайлы. Бейстационар планета жүйелерінің аспан-механикасы моделінде, әртүрлі қарқынмен изотропты емес өзгеретін, айнымалы массалы, сфералық көп дене мәселесі жұмыста қарастырылған. Бейстационар планета жүйелерінің эволюциясын зерттеу мақсатында, айнымалы массалы сфералық денелердің дифференциалды қозғалыс теңдеуі алынған. Жұмыстың ғылыми мәні планета жүйелерінің ұзақ уақыт периодындағы динамикалық эволюциясының айнымалы массалар әсерлерін зерттеумен байланысты. Сонымен қатар бөлшектердің аккрециялануына байланысты орталық жұлдыздың массасының азаюы қалай ескерілсе, планеталардың массасының көбеюі де ескеріледі. Планета жүйелерінің дифференциалдық теңдеуі, Мещерскийдің теңдеуі арқылы, абсолютті координаталар жүйесінде және салыстырмалы координаталар жүйесінде алынған.

Салыстырмалы координаталар жүйесінде алынған дифференциалдық теңдеулер негізінде, квазиконустық қима бойынша, апериодты қозғалысты назарға ала отырып, Пуанкаре элементтерінің екінші жүйесіндегі лездік аналогтарындағы канондық теңдеулерде және Лагранж теңдеулері түріндегі лездік элементтерінде қозғалыс теңдеуі қорытылып шығарылды.

Түйін сөздер: бейстационар жұлдыз, планета жүйесі, айнымалы масса, көп дене мәселесі, оскуляция элементтері.

\section{М.Дж. Минглибаев, А.Б. Кошербаева}

КазНУ им. аль-Фараби, Алматы, Казахстан

\section{ДИФФЕРЕНЦИАЛЬНЫЕ УРАВНЕНИЯ ПЛАНЕТНЫХ СИСТЕМ}

Аннотация. Исследование происхождения и эволюции экзопланетных систем - одна из актуальных тем небесной механики и астрономии. В 1950 году была сделано открытие экзопланетных систем. С момента обнаружения экзопланетных систем разными методами изучаются их появления и динамическая эволюция. В настоящее время используется восемь методов обнаружения экзопланетных систем. Из них наиболее популярные - два метода. Первый метод - метод лучевых скоростей, с использованием этого метода начались открытия экзопланетных систем около родительской звезды. Второй метод - это метод транзитов с появлением миссии космического телескопа «Кеплер». В этих методах используется классическая небесная механика, где массы тел считается постоянными и используются формулы классического кеплеровского движения. Однако реальные космические системы нестационарные. Различные комбинации динамических эффектов нестационарных гравитирующих тел, таких как переменность массы, переменность размеров и переменность формы, предопределяют богатое разнообразие эволюционных путей гравитирующих систем. Исследования этих явлений в небесно-механическом аспекте необходимы для понимания природы динамической эволюции планетных систем. В настоящее время интенсивно разрабатываются нестационарные динамические задачи астрономии. Изменение со временем массы, размеров, формы и других физических параметров небесных тел допускает экспериментальное определение. Поэтому необходимо формулирование и исследование динамических задач, принимая во внимание изменение со временем этих физических параметров. Большинство известных экзопланет вращаются вокруг звезд спектральных классов F, G, K и М. Массы этих звезд переменные и эффект переменность центральной звезды на движение планет мало изучены. Однако дифференциальное уравнение движения с учетом переменности масс центральной звезды не интегрируемые, поэтому проблема обычно исследуется методами теории возмущений. При этом предпочтительны уравнение возмущенного движения на базе апериодического движения по квазиконическому сечению в форме уравнения Лагранжа и канонические уравнения возмущенного движения. 
В работе рассматривается задача многих сферических тел с переменными массами, изменяющимися неизотропно, в различных темпах как небесно-механическая модель нестационарных планетных систем. В статье получены дифференциальные уравнения движения сферических тел с переменными массами с целью исследование эволюции нестационарных планетных систем. Научная значимость работы заключается в исследовании эффектов переменности масс динамической эволюций планетной системы в длительный период времени. При этом учитывается как убывание масс родительской звезды, так и рост масс планет из-за аккреции вещества. Исходя из уравнений Мещерского, получены дифференциальные уравнения движения планетных систем в абсолютной системе координат и в относительной системе координат. На базе полученных дифференциальных уравнений в относительной системе координат, выведены уравнения движения в оскулирующих элементах в форме уравнения Лагранжа и канонические уравнения в оскулирующих аналогах второй системы элементов Пуанкаре на базе апериодического движения по квазиконическому сечению.

Ключевые слова: нестационарная звезда, планетная система, переменная масса, задача многих тел, оскулирующие элементы.

\section{Information about authors}

Minglibayev Mukhtar Zhumabekovich, al-Farabi Kazakh National University, Fesenkov Astrophysical Institute, Chief Researcher. minglibayev@gmail.com, https://orcid.org/0000-0002-8724-2648;

Kosherbayeva Aiken Bakutzhanovna, al-Farabi Kazakh National University, doctoral student, kosherbaevaayken@gmail.com, https://orcid.org/0000-0002-8223-2344

\section{REFERENCES}

[1] http://spacetimes.ru/exoplanets

[2] http://exoplanetarchive.ipac.caltech.edu

[3] http://exoplanet.eu $260 \mathrm{p}$.

[4] Omarov T.B. (2002) (Editor) Non-Stationary Dynamical Problems in Astronomy. New-York: Nova Science Publ.Inc.

[5] Bekov A.A., Omarov T.B. (2003) The theory of orbits in non-stationary stellar systems // Astron. Astrophys. Trans. Vol. 22(2). P.145-153.

[6] Eggleton P. (2006) Evolutionary processes in binary and multiple stars. Cambridge University Press. 332 p.

[7] Minglibayev M.Zh. (2012) Dinamika gravitiruyushchikh tel s peremennymi massami i razmerami. LAP LAMBERT Academic Publishing. $224 \mathrm{p}$.

[8] Minglibayev M.Zh., Mayemerova G.M. (2014) Evolution of The Orbital-Plane Orientations in the Two-Protoplanet Three-Body Problem with Variable Masses // Astronomy Reports. Vol.91(9). P.762-772.

[9] Luk'janov L.G. (1983) Ob uravnenijah dvizhenija zadachi mnogih tel s peremennymi massami // Astron. zhurn. Vol.60(1). P. 181-184

[10]Cherepashchuk A.M. (2013) Tesnyye dvoynyye zvezdy. Chast' II. M.: Fizmatlit. P.572. (in Russ.) $260 \mathrm{p}$.

[11]Prokopenya A.N. (2005) Reshenie fizicheskih zadach c ispolzovaniem sistemy Mathematica, BSTU Publishing, Brest,

[12]Prokopenya A.N., Chichurin A.V. (1999) Primenenie sistemy Mathematica k resheniju obyknovennyh differencial'nyh uravnenij. Minsk: BGU. 265 p. 


\title{
Publication Ethics and Publication Malpractice in the journals of the National Academy of Sciences of the Republic of Kazakhstan
}

For information on Ethics in publishing and Ethical guidelines for journal publication see http://www.elsevier.com/publishingethics and http://www.elsevier.com/journal-authors/ethics.

Submission of an article to the National Academy of Sciences of the Republic of Kazakhstan implies that the work described has not been published previously (except in the form of an abstract or as part of a published lecture or academic thesis or as an electronic preprint, see http://www.elsevier.com/postingpolicy), that it is not under consideration for publication elsewhere, that its publication is approved by all authors and tacitly or explicitly by the responsible authorities where the work was carried out, and that, if accepted, it will not be published elsewhere in the same form, in English or in any other language, including electronically without the written consent of the copyright-holder. In particular, translations into English of papers already published in another language are not accepted.

No other forms of scientific misconduct are allowed, such as plagiarism, falsification, fraudulent data, incorrect interpretation of other works, incorrect citations, etc. The National Academy of Sciences of the Republic of Kazakhstan follows the Code of Conduct of the Committee on Publication Ethics (COPE), and follows the COPE Flowcharts for Resolving Cases of Suspected Misconduct (http://publicationethics.org/files/u2/New_Code.pdf). To verify originality, your article may be checked by the originality detection service Cross Check http://www.elsevier.com/editors/plagdetect.

The authors are obliged to participate in peer review process and be ready to provide corrections, clarifications, retractions and apologies when needed. All authors of a paper should have significantly contributed to the research.

The reviewers should provide objective judgments and should point out relevant published works which are not yet cited. Reviewed articles should be treated confidentially. The reviewers will be chosen in such a way that there is no conflict of interests with respect to the research, the authors and/or the research funders.

The editors have complete responsibility and authority to reject or accept a paper, and they will only accept a paper when reasonably certain. They will preserve anonymity of reviewers and promote publication of corrections, clarifications, retractions and apologies when needed. The acceptance of a paper automatically implies the copyright transfer to the National Academy of sciences of the Republic of Kazakhstan.

The Editorial Board of the National Academy of sciences of the Republic of Kazakhstan will monitor and safeguard publishing ethics.

Правила оформления статьи для публикации в журнале смотреть на сайте:

www:nauka-nanrk.kz

\author{
ISSN 2518-1483 (Online), ISSN 2224-5227 (Print)
}

http://reports-science.kz/index.php/en/archive

Редакторы: М. С. Ахметова, Г. Б. Халидуллаева, Д. С. Аленов

Верстка на компьютере А.М. Кульгинбаевой

Подписано в печать 07.04.2020.

Формат 60x881/8. Бумага офсетная. Печать - ризограф.

11 п.л. Тираж 500. Заказ 2. 